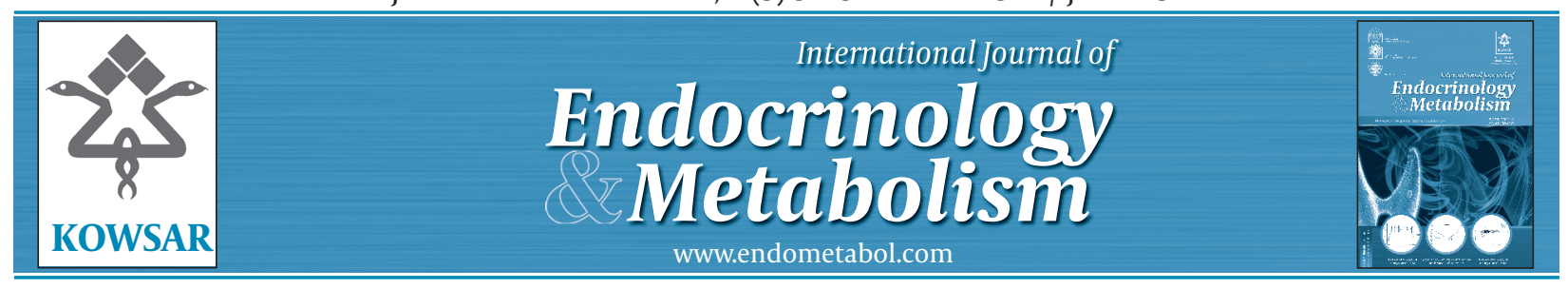

\title{
A Long Way Is Ahead of Prediction of Menopause!
}

\author{
Fahimeh Ramezani Tehrani ${ }^{{ }^{*}}$ \\ ${ }^{1}$ Reproductive Endocrinology Research Center, Research Institute for Endocrine Sciences, Shahid Beheshti University of Medical Sciences, Tehran, IR Iran
} A R T I C L E I N F O

Article type:

Editorial

Article history:

Received: 10 Jun 2012

Revised: 12 Jun 2012

Accepted: 13 Jun 2012

Keywords:

Menopause

Fertility

Menopause, an important reproductive milestone, is associated with complete cessation of fertility. There is considerable individual variation in the age of onset of menopause; its average is 51years but varies from 40 to 60 years and about 10\% of women reach menopause by the age of 45 years (1).

Over the past two decades, precise prediction of age at menopause for individual women has attracted a lot of interest. Nowadays many women postpone their childbearing but with a lot of anxiety about the amount of time remains before reaching menopause. The prediction of age at menopause would possibly help these women to make a reasonable decision regarding their family planning.

Various endocrinological and sonographic markers have been used to predict age at menopause and to assess ovarian reserve status $(2,3)$. In spite of subtle changes in endocrine regulation of ovarian function with advancing age the majority of these markers are not clinically useful for prediction of menopause. The majority of changes on these factors is happening during the last years of reproduction and is not appropriate for an early prediction; furthermore they have significant variation from one

\footnotetext{
* Corresponding author: Fahimeh Ramezani Tehrani, Research Institute for Endocrine Sciences, No. 24 Parvaneh, Yaman Street, Velenjak, P.O.Box:19395-4763, Tehran, IR Iran. Tel/ Fax: +98-2122432500, E-mail: ramezani@endocrine.ac.ir, framezan@ post.harvard.edu

DOI:10.5812/ijem.6836

Copyright @2012 RIES \& IES. Publish by Kowsar Corp. All rights reserved.
}

Implication for health policy/practice/research/medical education:

Prediction of age at menopause would help women seeking advice regarding their family planning.

- Please cite this paper as:

Ramezani Tehrani F. A Long Way Is Ahead of Prediction of Menopause!. Int J Endocrinol Metab. 2012;10(3):521-2. DOI: 10.5812| ijem.6836

Publish by Kowsar Corp. All rights reserved.

menstrual cycle to another as a result a single measurement does not provide a reliable and valid assessment of reproductive status (4).

There are recent clinical insights into Anti Mullerian Hormone (AMH) as a promising biomarker for assessment of the ovarian follicular status (5). Anti-Mullerian hormone $(\mathrm{AMH})$ is a glycoprotein that belongs to the transforming growth factor $\beta$ superfamily. It is mainly expressed by the Sertoli cells in the fetal testis and by the Granolosa cells of ovarian follicles (6). The physiological role of AMH in female reproduction is not fully described however animal studies demonstrated its role in both the inhibition of primordial to primary follicle growth and also in the follicular responsiveness to follicular stimulating hormone (FSH) $(7,8)$.

AMH has several characteristics that make it theoretically as a suitable biologic marker for ovarian aging. AMH is secreted exclusively in ovarian follicles and gradually decreases with increasing age $(4,9)$. It is independent of the menstrual cycle and only minor fluctuations in serum concentrations have been observed during the normal menstrual cycle that is consistent with the continuous non cyclic growth of small follicles (9). Its level remains almost constant from one cycle to another and has a high intra class correlation coefficient as a result only one measurement will provide a reliable estimate of its mean in each individual woman $(10,11)$.

Over the past decade much effort has been put into a precise prediction of individual age at menopause based 
on the serum concentration of AMH (12-14). There are a limited number of cohort studies that used various statistical modeling to provide a tool for clinicians for menopausal age's prediction $(14,15)$. However the existing cohorts have the limitation of not including women from early reproductive age and not long-enough duration of follow ups.

It seems that AMH has the potential capacity for assessment of ovarian ageing but we have a long way ahead to use it as a clinical tool for simple and reliable prediction of age at menopause. Several large longitudinal study representative of the general population of various ethnicities with a long-enough duration, starting with women in their early reproductive period with a comprehensive assessment of their clinical, biochemical and genetic profile are urgently needed.

\section{Acknowledgments}

None declared.

\section{Financial Disclosure}

None declared.

\section{Funding/Support}

None declared.

\section{References}

1. Gold EB, Bromberger J, Crawford S, Samuels S, Greendale GA, Harlow SD, et al. Factors associated with age at natural menopause in a multiethnic sample of midlife women. Am JEpidemiol. 2001;153(9):865-74

2. Burger HG, Hale GE, Robertson DM, Dennerstein L. A review of hormonal changes during the menopausal transition: focus on findings from the Melbourne Women's Midlife Health Project.
Hum Reprod Update. 2007;13(6):559-65.

3. Lambalk CB, van Disseldorp J, de Koning $\mathrm{CH}$, Broekmans $\mathrm{FJ}$. Testing ovarian reserve to predict age at menopause. Maturitas. 2009;63(4):280-91.

4. van Rooij IA, Broekmans FJ, Scheffer G], Looman CW, Habbema JD, de Jong FH, et al. Serum antimullerian hormone levels best reflect the reproductive decline with age in normal women with proven fertility: a longitudinal study. Fertil Steril. 2005;83(4):979-87.

5. Barton AL. Anti-Mullerian hormone: a new marker for ovarian function. Ann Clin Biochem. 2008;45(Pt 2):231.

6. Lee MM, Donahoe PK. Mullerian inhibiting substance: a gonadal hormone with multiple functions. Endocr Rev.1993;14(2):152-64.

7. Durlinger AL, Gruijters MJ, Kramer P, Karels B, Ingraham HA Nachtigal MW, et al. Anti-Mullerian hormone inhibits initiation of primordial follicle growth in the mouse ovary. Endocrinology. 2002;143(3):1076-84.

8. Durlinger AL, Gruijters MJ, Kramer P, Karels B, Kumar TR, Matzuk MM, et al. Anti-Mullerian hormone attenuates the effects of FSH on follicle development in the mouse ovary. Endocrinology. 2001;142(11):4891-9.

9. Hehenkamp WJ, Looman CW, Themmen AP, de Jong FH, Te Velde ER, Broekmans FJ. Anti-Mullerian hormone levels in the spontaneous menstrual cycle do not show substantial fluctuation.J Clin Endocrinol Metab. 2006;91(10):4057-63.

10. Tehrani FR, Solaymani-Dodaran M, Azizi F. A single test of antimullerian hormone in late reproductive-aged women is a good predictor of menopause. Menopause. 2009;16(4):797-802.

11. Tehrani FR, Solaymani-Dodaran M, Hedayati M, Azizi F. Is polycystic ovary syndrome an exception for reproductive aging? Hum Reprod. 2010;25(7):1775-81.

12. Sowers MR, Eyvazzadeh AD, McConnell D, Yosef M, Jannausch ML, Zhang D, et al. Anti-mullerian hormone and inhibin B in the definition of ovarian aging and the menopause transition. J Clin Endocrinol Metab. 2008;93(9):3478-83.

13. Freeman EW, Sammel MD, Lin H, Gracia CR. Anti-mullerian hormone as a predictor of time to menopause in late reproductive age women. J Clin Endocrinol Metab. 2012;97(5):1673-80.

14. Broer SL, Eijkemans MJ, Scheffer GJ, van Rooij IA, de Vet A, Themmen AP, et al. Anti-mullerian hormone predicts menopause: a long-term follow-up study in normoovulatory women. J Clin Endocrinol Metab. 2011;96(8):2532-9.

15. Tehrani FR, Shakeri N, Solaymani-Dodaran M, Azizi F. Predicting age at menopause from serum antimullerian hormone concentration. Menopause. 2011;18(7):766-70. 